\title{
Participation Styles in Elementary Physical Education
}

\author{
Jan-Erik Romar1, Jonas Nygård1, Tomas Smedman', Emyr Williams² \\ ${ }^{1}$ Faculty of Education, Åbo Akademi University, Vasa, Finland \\ ${ }^{2}$ Kinesiology Department, California State University, Long Beach, USA \\ Email: jromar@abo.fi
}

Received 15 January 2015; accepted 3 February 2015; published 5 February 2015

Copyright $(2015$ by authors and Scientific Research Publishing Inc.

This work is licensed under the Creative Commons Attribution International License (CC BY). http://creativecommons.org/licenses/by/4.0/

(c) $\underset{\mathrm{EY}}{\mathrm{EY}}$ Open Access

\begin{abstract}
Both observational data and direct measurement of student activity seem to indicate a large variance in student activity during physical education lessons. The aim of this study was to identify participation styles during elementary physical education lessons by using multiple data sources. A class of fifth grade students $(\mathrm{N}=17)$ and a class of sixth grade students $(\mathrm{N}=14)$ were taught by a physical education specialist for three lessons each. Both classes had coed physical education lessons and all students were systematically analyzed by using heart rate measurement, systematic observation and perceived exertion. Each lesson was videotaped for further analysis. Finally, six high and five low skilled students were formally interviewed after the last lesson about their experiences in physical education. The results indicated four different participation styles among the students in these physical education elementary classes. These were low skilled fighters, low skilled avoiders, high skilled fighters and high skilled avoiders. Several contextual factors are contributors to these participation styles. The main reasons for this appear to be differences in students' fitness levels, physical activity behavior and interest in physical education. This large variation among students shows that teachers need to treat each student individually.
\end{abstract}

\section{Keywords}

Physical Education, Student Physical Activity, Participation Style

\section{Introduction}

Several studies indicated that a large number of students had positive attitudes and experiences of physical education (Palomäki \& Heikinaro-Johansson, 2011; Subramaniam \& Silverman, 2007). Research conducted by Lauritsalo, Sääkslahti, \& Rasku-Puttonen (2012), however, outlined some factors that determined both positive 
and negative attitudes toward PE. This is nothing new. Locke (1987) argued that the real curriculum for many students was considerably different from the formal intensions of the teacher. Similarly, Dodds (1985) concluded that students learnt all sorts of things other than what the teachers intend to teach. The nature of teaching is complex and multiple variables affect student learning. Therefore, Amade-Escot \& Amans-Passaga (2007) proposed that individual, activity and environmental aspects of teaching/learning were inseparable, and that content in physical education must be considered through this multidimensional perspective.

Often sport pedagogy research tends to infer that the experiences of all participants in a given instructional context are similar. This is not the case and qualitative research has described various participation styles of pupils in school physical education classes and has revealed that participants in the same instructional setting often have very different experiences. Griffin $(1984 ; 1985)$ reported that hidden forces drove different subgroups to learn diverse behavior patterns in physical education classes. Within mixed-gender classes on various sports and games, Griffin (1984) noted that at the top of the girls' hierarchy were the athletes who were well-skilled, with high visibility and involvement. Slightly less skilled but with mixed involvement (although interested in game playing) were the junior varsity players. Conversely, cheerleaders were low-skilled players; however, they enjoyed game play and were excited when their team scored whereas the unskilled lost souls appeared to be passive and confused by the game. The femme fatales on the other hand had the skill to participate successfully, however they chose to limit their active involvement. Instead, their priorities were their appearance and attracting boys. The system beaters did everything possible to avoid taking part in lessons and often achieved this goal by producing excuse notes. In addition to Griffin's (1984) participations styles in girls' physical education, Fisette (2013: p. 192-193) proposed a framework of self-identified barriers to girls' engagement in and enjoyment of physical education and they were described as "proving themselves to the boys", "girls are supposed to do girly things and boys are supposed to do boy-ee things", and "there's a risk of being embarrassed".

Griffin (1985) also described boys' participation styles in middle school physical education and machos were aggressive, loud, very well skilled, and viewed by other pupils as class leaders. They teased and harassed other boys and ignored the girls. Junior machos aspired to be machos but had less skill and physical presence and were often resentful of skilled girls. Nice guys possessed intermediate to advanced skill levels but were usually supportive of girls and did not engage in verbal or physical abuse of other boys. Invisible players, on the other hand, were loners who were skilled at simulating participation in game play, when they were actually doing nothing of the sort. Finally, the poorly skilled wimps were teased and abused by other pupils and often denied the right to participate in class activities, even if they wanted to. Tischler \& McCaughtry (2014) recently used the terms "sporty" and "less-sporty" to categorize boys in relation to their orientation to team sports. These students attributed levels of success to visible characteristics such as body type, fitness, degree of aggressiveness, and overall skill in sport. These factors made sporty boys stand out more positively and skillfully in comparison with less sporty boys. Content, pedagogy, and student-teacher interaction in traditional physical education led all students to perceive static and well-pronounced masculinity hierarchies. However, the students felt that the teaching of physical education was manifested differently in an adventure physical education model than what they perceived to be the case in sport-based physical education classes.

Kalaja (2012) used a quantitative approach with data from fundamental motor skill (FMS) tests and motivational and perceived competence questionnaires to categorize students. Three cluster groups of students were found in Finnish grade seven physical education classes. The first group consisted of students with low skills and low motivation and included students with low FMS, perceived competence, and self-determined motivation toward physical education. The second group comprised of students with high skills and low motivation and consisted of students with high FMS and low perceived competence and self-determined motivation toward physical education. The final category of students was the high skills/high motivation group, which included students with relatively high FMS and high perceived competence and motivation. A comparison of cluster groups with physical activity indicated that "high skills/high motivation" students were engaged in significantly higher self-reported engagement in leisure physical activity than the other two clusters.

Cothran (2010) combined quantitative data with students' interviews in studying underlying values and assigned meanings of high school students by quantitatively clustering similar students together. Five different groups of students were reported. One group was named "Playful friends" and for them physical education provided opportunities to be with friends, have fun and play, while still getting a good grade. "Competitors" valued skill development and the competitive phase in game play during the multi-activity approach. "Friendly learners" were described by the opportunity to be with friends and similarly learn and get good grades. "Cooperative 
learners" emphasized appropriate student behavior, learning how to work together and getting good grades. Finally, the "Social comparison" group valued grades and their relations to other students in the class and not being embarrassed.

Both the qualitative and quantitative studies show that students are not a uniform group with all students valuing, experiencing and behaving similarly in physical education. Students experience physical education differently and those differences are often related to gender and ability. Traditional team sports are often on the basis of the multi-activity model, which rewards size and effort. The model also includes a great deal of competition and public display where low skilled or less confident students often report negative experiences and feeling of being marginalized (Smith \& Goc Karp, 1996). Constantinides (2011) described the profile of obese students' experiences in physical education. These students perceived physical education to be of little or no benefit to them. They indicated a desire to become invisible during the lesson as they perceived that the activities emphasized in physical education made them feel uncomfortable in front of their classmates. Moreover, participating in traditional team sport class activities allowed their peers to publicly view their physical limitations, such as running slowly or having limited skill in a variety of activities. These obese students admitted to looking for excuses to avoid participation in physical education.

Student participation in physical education can be objectively measured by analyzing student physical activity during lessons. Several reviews (Fairclough \& Stratton, 2005a, 2006; Stratton, 1996) of student physical activity have showed that students engage in moderate-to-vigorous physical activity (MVPA) about one third of physical education lesson time. This is less than the 50\% recommended by Healthy People 2010. The amount of student physical activity in physical education seems to differ depending on the context, lesson content, teacher behavior, and student background variables. Student grade level is an example of one context variable, and studies show that elementary school students spend more physical education lesson time in MVPA compared with secondary school students (Fairclough \& Stratton, 2005b; Gao, Hannon, \& Carson, 2009; Hodges Kulinna, Martin, Lai, Kliber, \& Reed, 2003; Singerland, Oomen, \& Borghouts, 2011; Surapibooncha, Furney, Reardon, \& Murray, 2012). Although most descriptive studies report that MVPA levels lower below $50 \%$ of lesson time, Jaakkola, Liukkonen, Laakso, \& Ommundsen (2008) reported high MVPA (61\%) for ninth grade students during game play, a football lesson. Additionally, Slingerland, Haerens, Cardon, \& Borghouts (2014) reported a $74 \%$ and $64 \%$ MVPA level in game play for boys and girls respectively.

Alternatively, mean and maximal heart rates are other variables that can be used to evaluate activity levels. Studies have showed that average heart rate in physical education lessons ranges from $114 \mathrm{bpm}$ (Laurson, Brown, Cullen, \& Dennis, 2008), 132 bpm (Lyyra, Heikiaro-Johansson, Johansson, \& McEvoy, 2008), 135 bpm (Sarradel et al., 2011), 142 bpm (Wydra, 2009), 140 bpm (Gao, Hannon, \& Carson, 2009) and 147 bpm (Jaakkola et al., 2008) to 159 bpm (Van Acker et al., 2010).

The physical activity intensity levels similarly vary based on different content and teaching styles. Chow et al. (2008) reported that students engaged in high levels of MVPA in lessons focusing on tennis, distance dancing and free play activities, while table tennis and long jumping provided smaller proportions of MVPA. Several other studies (Fairclough \& Stratton, 2005b; 2006) have indicated higher student activity levels in team game lessons. In the Netherlands, students engaged in more moderate to-vigorous physical activity during swimming classes (52\%) than during non-swimming classes (40\%) (Cardon, Verstraete, De Clercq, \& De Bourdeaudhuij, 2004). During adventure education lessons, students spent less time in MVPA compared with traditional physical education lessons (Gehris, Myers, \& Whitaker, 2012).

Several studies comparing boys' and girls' MVPA engagement during physical education showed higher levels of MVPA among boys when compared with girls during coeducational classes. This distinction has been noted when physical activity has been assessed using heart rate monitoring (Fairclough \& Stratton, 2005b; Hodges Kulinna et al., 2003; Slingerland et al., 2014; Stratton, 1996), pedometers (Hannon \& Ratliffe, 2005), accelerometry (Whipp, Dimmock, \& Jackson, 2013) and direct observation (McKenzie, Marshall, Sallis, \& Conway, 2000; McKenzie, Prochaska, Sallis, \& LaMaster, 2004). In addition, Gutierrez \& García-López (2012) observed student behavior in invasion ball games and reported that boys participated more in offensive play with the ball, while the girls displayed more off-the-task (spectator-player) behaviors.

Different forms of student ability can also affect students' physical activity levels during physical education lessons and Fairclough \& Stratton (2005b) reported that high-ability students were more active than the average- and low-ability students. Similarly, Spessato, Gabbard, \& Valentini (2013) measured physical activity levels of $5-10$ years old children with pedometers and found that students with high motor competency were sig- 
nificantly more active during physical education lessons than children with low and moderate motor competency. Conversely, Fairclough (2002) reported a weak relationship between aerobic capacity and MVPA in girls' high school physical education. Also students with higher perceived competence showed higher amounts of MVPA during game play in basketball (Slingerland et al., 2013). Nevertheless, Lyyra et al. (2008) found that middle school students with low leisure-time activity levels were as active during physical education lessons as students with high leisure-time activity levels. In addition, there are conflicting results in respect to student body composition. Spessato et al. (2013) found no significant correlation between BMI and MVPA, while Fairclough (2002) found that physical activity during physical education was inversely related to students' body fat percentage.

Additional studies (How, Whipp, Dimmock, \& Jackson, 2013; Perlman, 2013) showed that teaching behaviors that aligned with an autonomy-supportive teaching approach could facilitate greater in-class MVPA levels. Other studies (Perlman, 2012; Wallhead, Garn, Vidoni, \& Youngberg, 2013) also reported that teachers using the Sport Education Model (Siedentop, Hastie, \& van der Mars, 2011) provided amotivated students with an increased opportunity to engage in higher levels of physical activity.

As research related to motivational aspects shows an effect on student activity, perceived exertion is also a factor that relates to physical activity behavior in children. Rating of perceived exertion has been suggested to be an appropriate measure of exercise intensity. It is assumed to represent many factors affecting the intensity of physical activity, such as students' psychological state and training status. Borg (1982) designed the first rating of perceived exertion (RPE) scale and it had been shown to be a simple and valid method for quantifying whole training session intensity for children and adolescents (Chen, Fan, \& Moe, 2002; Pfeiffer, Pivarnik, Womack, Reeves, \& Malina, 2002). Therefore, perceived exertion could provide additional understanding of students' physical activity during PE lessons and Marmeleira, CarrasqueiraAldeias, \& dos Santos Medeira da Graça (2012) found that students experienced a light degree of physical exertion in physical education lessons with an average of 11.6 on the Borg scale. In addition, Wydra (2009) reported that $43 \%$ of the students perceived the physical education lesson to be at least somewhat demanding (at least level 13 of 20 on the Borg scale).

The research seems to indicate a large variation in student activity depending on student variables and context. Moreover, different ways of measuring student activity will provide additional variation in the data. Fairclough \& Stratton (2005c) analyzed MVPA with observation and heart rate measurement and found that student activity differed markedly, with heart rate measurement showing higher values than observational data. On the other hand, Marmeleira, CarrasqueiraAldeias, \& dos Santos Medeira da Graça (2012) reported that both the number of steps and the rate of perceived exertion were correlated with heart rate measurements of students' during physical activity. The inconsistence between different physical activity measures and context specificity highlights the advantage of combining instruments when assessing students' physical activity. Researchers (Fairclough, 2002; Lyyra et al., 2008) have suggested that different objective measurements and student selfreports will be beneficial in order to acquire a deeper understanding of student physical activity in physical education lessons. In addition, studies reviewed in this paper generally report physical activity as a class or group mean. Moreover, in identifying different student groups researchers have relied on qualitative observations, student interviews, questionnaires, and skill tests. Therefore, the aim of this study was to identify and understand participation styles during elementary physical education lessons by using multiple data sources to analyze student activity.

\section{Methods}

A physical education specialist taught two classes, a fifth grade class with 17 students and a sixth grade class with 14 students, for three lessons each. The male teacher, with a master's degree, had six years of full time teaching experience and had been employed at this elementary school for the last five years. This teacher taught with a direct-instruction style and actively supervised his students. This public elementary school (Grades $1-6$ ) served 100 students from predominantly middle socioeconomic status neighborhoods.

Both physical education classes were coeducational and did not share the activity space with any other classes. The data collection took place during an indoor multi-activity unit (ballgames, fitness) in a gym with about 400 $\mathrm{m}^{2}$ available space. Each lesson lasted from 39 to 48 minutes with generally $10 \%$ of the time allocated for pre and post management and the remaining time for skill instruction, circuit training, station teaching and game play. The first lesson for both groups consisted of a short aerobics warm-up followed by circuit training. Subsequent lessons for both classes consisted of skill practice and game play, in team handball for the fifth grade class and basketball for the sixth grade class. The teacher was instructed to teach the lessons as he normally would. 
He was asked to not place any unusual emphasis on tasks that would increase heart rates more than normal (e.g., fitness work or circuit training), unless the lesson would normally have included those types of activities.

Heart rate measurement, systematic observation and perceived exertion were systematically analyzed from all students. Each lesson was videotaped with two cameras for further analysis and lesson time spent in MVPA were determined for each student. Seventy-nine individual calculations of physical activity were conducted during six physical education lessons. The study was explained and written informed parental consent was obtained prior to collecting data.

Heart rate (HR) telemetry has been shown to be a valid and reliable measurement of physical activity and has commonly been used in physical activity and physical education settings (Bar-Or, Bar-Or, Waters, Hirji, \& Russell, 1996; Treiber et al., 1989). Student heart rate levels during each PE-lesson were measured with Polar Team System heart-rate monitors, developed by Polar Electro, Finland. After students changed clothes and immediately before they entered the gymnasium, they were fitted with the heart rate telemeters. Heart rate was recorded every five seconds. The heart rate telemeters were removed at the end of the lessons. The HR data was downloaded to a portable PC using the specific software (Polar Advantage TM Polar Electro, Kempele, Finland) and subsequently analyzed.

Average heart rate, maximal heart rate and MVPA (Moderate to Vigorous Physical Activity) for each lesson were derived from the heart rate measurement. The percentage of lesson time in the category MVPA for each subject was calculated. The MVPA level represents moderate physical activity, which is the minimal intensity, required to reach the recommended level volume of health-related activity. The heart rate cut point for MVPA was $140 \mathrm{bpm}$ for both boys and girls and was based on values in previous research (Armstrong \& Bray, 1991; Armstrong, McManus, Welsman, \& Kirby, 1996).

System for Observing Fitness Instruction Time (SOFIT) was used to systematically observe students' level of MVPA. Lesson context, teacher promotion, and student physical activity levels can be analyzed with SOFIT. Validity of the activity level behaviors categories for use with school students has been verified (Rowe, Schuldheisz, \& van der Mars, 1997). However, in this study only student activity was analyzed and therefore lesson context and teacher promotion were not recorded. SOFIT is a momentary time sampling and interval recording instrument and quantifies physical activity levels on a scale from 1 to 5 . Non-MVPA categories comprise lying down (1), sitting (2) and standing (3), while MVPA (4 \& 5) includes behaviors that are equivalent to or more active that brisk walking and high intensity activities (VPA). Summing the proportion of lesson time spent in the walking and very active categories gives time spent in MVPA. The classification of physical activity levels was made by observing each student for five seconds and then five seconds for recording their level of active engagement level. Three students were observed during one viewing of the videotape and therefore each student was observed and recorded twice during one minute. A log of activities and coding rules was kept to provide consistency in coding. The technical descriptions of the SOFIT training manual (McKenzie, 1998) were used for observer training and data collection. Coding rules for MVPA categories of "walking" (Level 4) and "very active" (Level 5) were developed so that transitions from standing or sitting to walking or running, aerobics, actively engaged in abdominal curls, throwing balls, and running were coded as MVPA. Inter observer Agreement (IOA) check was performed by coding three different students from one lesson during the pilot study. The mean IOA percentage for students' MVPA was $96.4 \%$.

The Borg rate of perceived exertion scale is a widely used instrument to measure perceived exertion, or exercise intensity (Chen, Fan, \& Moe, 2002). Perceived exertion during the lessons was measured with the Borg RPE scale, which consists of numbered categories from 6 to 20 and verbal cues, from "very, very light" to "very, very hard". Students were familiarized with the scale before the first lesson, which included defining perceived exertion, anchoring the perceptual range, explaining the use of the scale and answering questions. All students rated the perceived exertion level and they estimated how hard they had been exercising at the end of each PE lesson.

Previous research has indicated differences in student activity patterns based on ability and gender. Consequently, we asked the physical education teacher to identify three low and three high skilled students from each class. The teacher had taught most of these students for three years and made his selection based on the students' motor skills, leisure activities, and interest and attitude towards physical education in school. Only two low skilled students in grade six received parental consent to participate in the study, therefore the total sample was 11 students, with six boys and five girls.

In addition to quantitative physical activity data from all students, the sub sample of subjects $(\mathrm{N}=11)$ categorized as either low or high skilled, participated in individual stimulated recall interviews after the third lesson. In 
the semi-structured interview, these students could see the printouts of their heart rate curve for each lesson while we also described the content and the structure of the lesson. Each interview with these students started with general and personal questions related to their leisure time and their perception of school physical education. The main focus of the interview was related to the students' perception of physical activity and their own effort during these physical education lessons.

All data were analyzed using SPSS for Windows (21.0). Means and standard deviations were calculated for each of the variables. As interview data were collected, two researchers transcribed all the interviews. After the first print version, the interviews were replayed in order to negate transcription errors. The first, second, and third authors first read several times through the interview transcripts to gain a broad overview of the material and thereby looking for trends and explanations. The analysis was data-driven and the descriptions were condensed from the data-base by using inductive constant comparison to describe these students.

Several strategies were used to show research trustworthiness and credibility (Guba \& Lincoln, 1989). Memos and notes were used to keep track of the data analysis which increased the confirmability of the study. Verbatim quotes from the students were taken in order to stay close to the data. For the result texts, we chose the most representative of the selected transcripts. Peer review and debriefing across researchers was conducted to assure credibility across findings. The peer debriefing process involved the researchers challenging each other's interpretation of the evidence.

The initial analysis of physical activity data showed a large variation between individual students and different lessons. Based on the physical activity measurements from all eleven students, we noted seven students with diverse values compared to other students in their class during these three lessons. We identified four different participation styles. These students' physical activity measurement showed either a higher level or a lower level in several data types compared to the rest of the students in the physical education lessons (see Table 1). These four participation styles will be described in depth in the result section.

Table 1. High and low skilled students' heart rate measurements.

\begin{tabular}{|c|c|c|c|c|c|c|c|c|c|c|c|c|c|c|c|}
\hline \multirow{2}{*}{$\begin{array}{c}\text { Student } \\
*\end{array}$} & \multicolumn{5}{|c|}{ Lesson one ${ }^{\#}$} & \multicolumn{5}{|c|}{ Lesson two ${ }^{\#}$} & \multicolumn{5}{|c|}{ Lesson three $\mathrm{e}^{\#}$} \\
\hline & Mean & $\operatorname{Max}$ & $\mathrm{Hr} \%$ & Sofit & Borg & Mean & Max & $\mathrm{Hr} \%$ & Sofit & Borg & Mean & Max & $\mathrm{Hr} \%$ & Sofit & Borg \\
\hline \multicolumn{16}{|c|}{ Low skilled fighter } \\
\hline Fred & 142 & 205 & 56.2 & 50 & 14 & & & absent & & & 148 & 193 & 70.2 & 49 & 16 \\
\hline Tim & 138 & 180 & 54.1 & 53 & 13 & 127 & 160 & 21.6 & 29 & 12 & 144 & 182 & 63.9 & 43 & 12 \\
\hline Other & 125 & 187 & 30.7 & 42.2 & 13.4 & 123 & 182 & 25.4 & 35.5 & 11.9 & 139 & 182 & 53.8 & 49.6 & 13.5 \\
\hline \multicolumn{16}{|c|}{ Low skilled avoider } \\
\hline Julia & 114 & 177 & 24.8 & 35 & 16 & 96 & 123 & 0.0 & 33 & 14 & 102 & 149 & 1.9 & 36 & 13 \\
\hline Other & 121 & 186 & 23.5 & 34.3 & 14.1 & 131 & 175 & 36.0 & 44.7 & 14.0 & 136 & 189 & 42.2 & 42.5 & 13.2 \\
\hline \multicolumn{16}{|c|}{ High skilled fighter } \\
\hline Lisa & 110 & 170 & 11.8 & 41 & 12 & 116 & 185 & 22.8 & 35 & 12 & 142 & 180 & 63.5 & 61 & 13 \\
\hline Jakob & 126 & 191 & 28.1 & 49 & 9 & 131 & 189 & 31.5 & 35 & 11 & 137 & 180 & 47.3 & 65 & 13 \\
\hline Other & 129 & 189 & 37.1 & 43.4 & 12.9 & 123 & 180 & 24.8 & 35.1 & 12.0 & 140 & 183 & 55.7 & 46.8 & 13.6 \\
\hline \multicolumn{16}{|c|}{ High skilled avoider } \\
\hline Ben & 114 & 187 & 17.2 & 43 & 11 & 110 & 176 & 9.9 & 36 & 11 & 137 & 180 & 53.2 & 71 & 15 \\
\hline Other & 128 & 188 & 35.9 & 43.7 & 12.7 & 124 & 181 & 26.3 & 35.0 & 12.0 & 140 & 183 & 55.7 & 47.4 & 13.4 \\
\hline Kati & 112 & 186 & 18.7 & 37 & 14 & 115 & 147 & 2.5 & 45 & 14 & 98 & 154 & 1.9 & 40 & 9 \\
\hline Other & 121 & 185 & 24.0 & 34.1 & 14.3 & 130 & 172 & 35.7 & 43.5 & 14.0 & 136 & 189 & 42.2 & 42.2 & 13.5 \\
\hline Total & 124 & 186 & 29.0 & 39.0 & 13.4 & 125 & 176 & 28.5 & 38.8 & 13.0 & 137 & 184 & 47.5 & 45.6 & 13.4 \\
\hline St De & 11.5 & 10.7 & 14.2 & 6.7 & 2.0 & 12.5 & 20.9 & 17.3 & 8.7 & 1.3 & 13.7 & 13.9 & 19.3 & 6.5 & 2.2 \\
\hline
\end{tabular}

Note: ${ }^{*}$ Other $=$ all other students in the same class; ${ }^{*}$ Mean $=$ mean heart rate; Max = maximal heart rate; Hr\% $=$ active lesson time in MVPA based on heart rate measurement $(\%)$; Sofit $=$ System for Observing Fitness Instruction Time (\%); Borg = Borg rate of perceived exertion. 


\section{Results}

We identified four different participation styles among the students in these physical education elementary classes from the quantitative data. Students were categorized as low skilled fighters, low skilled avoiders, high skilled fighters, and high skilled avoiders. Each individual student's value varied between different lessons, which also are shown in the variation in standard deviation between different measurements. The SOFIT value showed low variation and MVPA heart rate showed high variation, although these actually measure the same aspect of physical activity during physical education lessons.

A low skilled fighter was defined as a student who tries to be physically active despite a limited ability. This category consisted of two boys from grade five. Fred and Tim showed high average heart rates and a high MVPA heart rate percentage compared to the other students while the SOFIT value was about the same or somewhat lower than the other students. Their perceived exertion was higher than other students.

Both subjects are not involved in sport and spend most of their leisure time indoors. Fred said "I have a scrap car that I usually build on behind the house. And then I tend to sit at the computer the rest of the time". Physical education is not their favorite school subject although they have a positive attitude.

Enjoyment was reflected from student skill level and success in participation. Fred stated, "I get head ache from skating. I am poor at skating and I usually fall at least five times" and "Team handball is not so fun, because I'm so short that I can't really take the ball from people". The most fun activity is dodge ball when Fred said "I usually don't get hit, while I'm so small" and Tim liked dodge and basketball because "I'm rather good at it".

Both students told that the first lesson was hard and that circuit training was the most demanding activity during these lessons. Fred had high heart rate and Borg values during this lesson, nevertheless he stated "I did rather well and it was a little bit heavy" and that "I took it easier during the second lap, while I already was tired". This shows that the sense of effort and exhaustion is rather individual and both boys also mentioned that they sometimes avoid making maximal effort, as Tim reflected "I usually take it somewhat easy".

They still participated as well as they could and they didn't give up easily even if the exercises were demanding. Fred said "I was really exhausted afterwards" and Tim noted "it was supposed to go fast and you never got to rest". However, these students indicated that they didn't like the feeling of physical exhaustion. It seemed to be typical for these students that they forgot this unpleasant feeling when they had activities that the liked. And when the activity was less fun the focus shifted towards how physically demanding it was, which was noticed by Tim "You might not think of it then. I don't think so much on the heavy [drills] as it is fun".

A low skilled avoider was identified as a student who uses minimal effort. One girl from grade six was categorized as a low skilled avoider. During the first lesson with teacher lead fitness circuit training, Julia's heart rate and SOFIT values were close to the other students while rate of perceived exertion was higher. However, during the second and third lesson, her observed (SOFIT) physical activity was lower than other students and her heart rate measurements indicated a very low effort. Julia had zero percentage MVPA although she was observed being active during the second lesson.

Julia had previously participated in a cross country ski club but at the moment was training and taking care of horses four times a week. She was aware and pointed out the importance of being active during physical education lessons. However, she admitted that she could have tried harder during the PE lessons as she said "I could have showed more effort". She came up with excuses why her physical activity had been so low for general participation in physical education "Usually I have had a cold or not slept enough and having a headache, usually we have PE at the end of the day". Julia described that she is more active out-doors where there is more space to move around compared to the gym. She also described excuses for low participation in specific lessons, as this quote about the first lesson "I was not warmed up the first lap. So then I was stiff. During the second lap one was perhaps tired from the first. I tried at least during both laps".

Julia's favorite activities in physical education lessons were different ball games but she said "if the ball was close by, I took it but I did not run and get it if someone was close [to the ball]". During game play she also noticed that "perhaps we, without noticing it, let other [students] play more" and "sometimes one notice that one stands still without thinking about it". The strategy she used when something became demanding was to slow down the pace.

A high skilled fighter shows high effort and is active. This category consisted of Jakob and Lisa from grade five. The SOFIT analysis showed high values although their average heart rate was not high. The heart rate MVPA was high except for Lisa during the first lesson and the students showed a relatively high maximal heart 
rate during the lessons although the perceived exertion was low.

Both students were members of sport clubs and trained and competed several times a week. Lisa was a skier and Jakob played soccer. They had a positive attitude toward school physical education, which also was their favorite school subject. Jakob and Lisa liked both individual and team during sports physical education lessons.

These competitive students were motivated to actively participate in physical education lessons. Lisa said "I move a lot and show always high effort" and Jakob stated "I tried to be active and run all the time". In addition, Lisa stated that she saw physical education lessons as an opportunity for additional practice and to "improve the fitness". However, during the second lesson she indicated that she slowed down a little because she had a ski competition in the evening.

Both students seemed to like everything in physical education and they did not complain about anything. When asking Lisa what she enjoyed the most during these three lesson she responded that "The last one [lesson], it was the most demanding", which shows that she really wanted to be active. SOFIT data also showed that both students were very active during the third lesson. During game play they both indicated that they tried to run all the time, as Jakob stated: "I ran and jumped a lot and tried to steal the ball from the opponents, it was fun".

A high skilled avoider does not show more effort than necessary despite the high physical fitness level. Ben from grade five and Kati from grade six were identified as high skilled avoiders. These students' MVPA, average and maximal heart rate values showed generally low levels compared to other students in the class. The SOFIT observation data showed higher MVPA values than heart rate data and the perceived exertion was low.

Both students trained and competed several times a week in a ski club during their leisure time. These two students did not like everything during the physical education lessons, but Kati did like volleyball and skiing while Ben preferred team sports before individual sports. Ben and Kati admitted that they could have showed some more effort. It seemed that student performance was affected by how much fun they thought an activity was, as Kati said, "when we do fun things, I try harder. Ben also described that during the circuit training "I was tired during the second lap and at the end it was not so fun anymore". He did not enjoy this lesson and he said that "I did not become so tired" because he "did not have to run and could rest between the stations". He would not have tried harder even if the teacher would have supervised the station more actively. Kati, on the other hand, liked the circuit training because they did many different tasks and that she "really tried" and that she "did it for her own sake and that it is fun when you manage to do something".

During game play, Ben said he was running and "tries to get the ball and participate in the game". Kati, in turn, felt that she was involved but did all the time chase the ball and that "I perhaps was not really motivated". SOFIT analysis showed higher values than heart rate data for student MVPA levels, which could indicate that these students were actively participating in class activities but not pushing themselves physiologically in terms of their heart rate levels as a consequence of their high fitness levels.

\section{Discussion}

The aim of this study was to identify and understand participation styles during elementary physical education lesson by using multiple data sources in analyzing student activity. MVPA levels based on heart rate measurements and systematic observations from different lessons were found to be considerably lower (from $29.5 \%$ to $47.5 \%$ ) than the $50 \%$ recommendation as a goal for meeting MVPA guidelines in school PE lessons. These findings are in line with several other studies (Fairclough \& Stratton, 2005a, 2006; Stratton, 1996), although they are lower than MVPA guidelines. There is also a large variation between the three different lessons as well as between individual students. This considerable variance, which can be noticed particularly as high standard deviation values in heart rate MVPA data. The standard deviations of heart rate MVPA represented from $40 \%$ to $60 \%$ of the mean values, while the standard deviations for SOFIT was from $14 \%$ to $22 \%$, which illustrates the variability of physical activity within the same construct but with different measurement. This finding provides empirical support for Slingerland (2014) conclusion that one single method of physical activity assessment is not able to capture all activity dimensions concurrently. This variation in activity levels reflects that what the teacher can see is different from the physiological response in student body.

We identified four different participation styles from our data. First, a low skilled fighter was student with limited ability, who still tries to be physically active. Low skilled fighters are not involved in sport in leisure time which can be one explanation for the low success in physical education. The students are aware of not being as skilled as the other students in the class and attribute enjoyment to success in participation, and according to 
Tischler \& McCaughtry (2014) they would be categorized as "less-sporty" boys. However, low skilled fighters show effort, behave well and follow the teacher's instructions, and with that respect they could be both "friendly" and "cooperative" learners (Cothran, 2010). These students showed high heart rate values for their participation, which conflicts previous studies where high skilled students were more physically active during physical education lessons than low skilled students (Fairclough \& Stratton, 2005b; Slingerland, et al., 2013; Spessato, et al., 2013).

Julia was identified as a low skilled avoider and she did not use more effort than was needed. Particularly during ball game lessons, her physical activity heart rate measurements were at a very low level. Julia was not physically active during her leisure time although she spends time taking care of horses. She recognized that she was not very active during physical education lessons and she finds several different excuses for her inactivity. Such students were described by Griffin (1984) as system beaters and by Tousignant \& Siedentop (1983) as competent bystanders and they do everything possible to avoid taking part in the lesson by pretending to be on task and not disturbing the class structure. This low skilled avoider would also fit in to Kalaja's (2012) first cluster group of students, namely, students with low skills, perceived competence, and self-determined motivation towards physical education. Julia's participation style can also be compared with the way Constantinides (2011) described the profile of obese students' experiences in physical education. They looked for ways to avoid participation and to become invisible, while participating in traditional team sport made them feel uncomfortable in front of their classmates. Several researchers have showed lower physical activity levels for girls than for boys (Fairclough \& Stratton, 2005b; Hodges Kulinna et al., 2003; Slingerland, et al., 2013) as well as for low skilled students (Fairclough \& Stratton, 2005b; Slingerland, et al., 2013; Spessato, et al., 2013). Julia was particularly inactive during game play which might be related to gender stereotypes among students during game play. Gutierrez \& García-López (2012) also reported from observations of student behavior in invasion ball games that girls were more cooperative and showing off-the-task (spectator-player) behaviors while boys were active and focused more on the goal.

High skilled fighters were students that actively participated at a high level during physical education lessons. They were athletes training several times a week and physical education was their favorite school subject. The positive attitude was manifested in everything they participated in and the more challenging and demanding the activity was the more the enjoyed it. These students are typical examples of what Kalaja (2012) labelled as students with high motor skills and high perceived competence and motivation. In addition, according to Tischler \& McCaughtry (2014) these students were sporty students, who were skilled, fit and active. Moreover, Griffin (1984) described girls as athletes or junior varsity players, who were skilled with high involvement and interested in game play. Similarly, Griffin (1985) described boys as nice guys when they were skilled and enjoyed the game.

The final participation style was high skilled avoiders, who despite the high physical fitness level did not show more effort than they needed to take part in the physical education lessons. Although these students were athletic, they did not exhibit the positive attitudes towards physical education that high skilled fighters did. When they did not enjoy the activity they decreased their activity level, which is similar to the second cluster group; students with high skills and low motivation (Kalaja, 2012). Griffin (1984) also described girls in physical education as femme fatales and they were skilled students who choose to limit their active involvement. While heart rate data for students' MVPA levels showed lower values than observational physical activity data, it could be that these students participated as the other students but due to their high physical fitness levels they physiologically didn't reach a high effort level as measured by the heart rate monitors. Another possible explanation might be that when heart rate monitoring measures the physiological load and when physical education lessons are intermittent in nature and variable in duration and intensity, high skilled and fit students may recover faster and therefore the heart rate MVPA values are lower.

Although we found a large variation in physical activity between students and lessons, we have identified four different participation styles. When comparing these participation styles with previous qualitative and quantitative research about students in physical education, similar descriptions were found. This fact is also a validation of our results that students are not a uniform group where all students value, experience and behave in the same way. The nature of teaching physical education is complex and student learning and experiences are different from the teacher's intensions (Dodds, 1985, Locke, 1987). Students value non-educational features (mostly fun), and such as passing the class, and spending time and playing with friends (Cothran, 2010). Students also navigate within physical education lessons by altering their participation from low to high activity and visibility (Fi- 
sette, 2013). Therefore, it is important for teachers to see and recognize different participation styles in all students.

Physical activity makes physical education distinctive from other school subjects. However, the goals of school physical education are numerous and the general aim of physical education in Finland has been defined as building the students' self-esteem and positive physical self-concept through favorable school physical education experiences and to encourage cooperativeness and positive future sport and health behavior. These diverse goals conflict with reaching the physical activity guidelines in teaching physical education, while in this study students' average activity level was lower than the guidelines. Bennie \& Langan (2014) also reported that while the physical education teachers had optimistic ambitions, the teachers acknowledged that physical activity comprised just one aspect of their daily lessons. While physical education time is limited, there might raise the question whether the 50\% MVPA guideline is realistic. Nevertheless, high levels of active learning time must be balanced with instruction, feedback and reflection and that is where the teacher's expertise in meeting curriculum demands is important.

While student motivation and ability seem to be related to their physical activity, it is important to attend to the suitability of the physical education curriculum to optimize the participation of diverse students. This study and previous research (Constantinides, 2011, Fisette, 2013; Griffin, 1984, 1985; Smith \& Goc Karp, 1996; Tischler \& McCaughtry, 2014) might suggest that the large emphasis on team games in physical education could be responsible for this phenomenon. It seems doubtful that games dominated physical education with an emphasis on competition and on the learning of individualized skills, is able to motivate all different students. In response to this, Tischler \& McCaughtry (2014) noted that students felt that the climate was manifested differently in lessons based on the Adventure Physical Education model, although student physical activity level might be lower (Gehris et al., 2012). In addition, Gutierrez \& García-López (2012) concluded that the use of the pedagogical principles of Teaching Games for Understanding and the Sports Education model provides proper resources for challenging gender stereotypes in invasion games. New and different curriculums are not the single solution, but we see them as possibilities to strengthen students' opportunities to be equally active.

Despite some interesting findings, the study has several limitations. The short-term nature of data collection from three physical education lessons might provide just a narrow picture of physical education. We measured student physical activity, however reporting teacher perception and philosophy and an objective measure of teacher behavior would provide a more holistic and multidimensional perspective of the teaching and learning in the class. It also needs to be acknowledged that generalizability of our results to other school contexts could be limited by the modest sample size and by potential selection bias. Hence, further studies are needed to examine whether these participation styles can be observed in other contexts and cultures. Additionally, further research is needed to confirm whether approaches intended to increase participation have positive or negative implications for the diverse student population.

\section{Conclusion}

Physical education has the potential to positively impact children by providing opportunities for active learning. Several contextual factors are contributors to our reported participation styles. The main reason for this appears to be differences in students' fitness levels, physical activity behavior and interest in physical education. Student performance is both dynamic and temporal within the context of physical education, and a key to success here is the ability of the teachers to see, understand and make connections between students' backgrounds and their behavior in class. This reinforces the importance of good teaching skills as a potential means to help all students in the class. The large variation among individual students shows that each student should be treated separately and that a "one size fits all" approach to teaching physical education doesn't work.

\section{References}

Amade-Escot, C., \& Amans-Passaga, C. (2007). Quality Physical Education: A Review from Situated Research (1995-2005). International Journal of Physical Education, 43 and 44 (4 and 1), 4-11 and 162-172. https://hal-univ-tlse2.archives-ouvertes.fr/hal-00782633/document

Armstrong, N., \& Bray, S. (1991). Physical Activity Patterns Defined by Continuous Heart Rate Monitoring. Archives of Disease in Childhood, 66, 245-247. http://dx.doi.org/10.1136/adc.66.2.245

Armstrong, N., McManus, A., Welsman, J., \& Kirby, B. (1996). Physical Activity Patterns and Aerobic Fitness among Prepubescents. European Physical Education Review, 2, 19-29. http://dx.doi.org/10.1177/1356336X9600200103 
Bar-Or, T., Bar-Or, O., Waters, H., Hirji, A., \& Russell, S. (1996). Validity and Social Acceptability of the Polar Vantage XL for Measuring Heart Rate in Preschoolers. Pediatric Exercise Science, 8, 115-121.

Bennie, A., \& Langan, E. (2014). Physical Activity during Physical Education Lessons: A Qualitative Investigation of Australian PE Teacher Perceptions. International Journal of Qualitative Studies in Education, 1-19. http://dx.doi.org/10.1080/09518398.2014.933914

Borg, G. (1982). Psychophysical Bases of Perceived Exertion. Medicine and Science in Sports and Exercise, 14, $377-381$. http://dx.doi.org/10.1249/00005768-198205000-00012

Cardon, G., Verstraete, S., De Clercq, D., \& De Bourdeaudhuij, I. (2004). Physical Activity Levels in Elementary-School Physical Education: A Comparison of Swimming and Nonswimming Classes. Journal of Teaching in Physical Education, 23, 252-263.

Chen, M. J., Fan, X., \& Moe, S. T. (2002). Criterion-Related Validity of the Borg Ratings of Perceived Exertion Scale in Healthy Individuals: A Meta-Analysis. Journal of Sports Sciences, 20, 873-899. http://dx.doi.org/10.1080/026404102320761787

Chow, B. C., McKenzie, T. L., \& Louie, L. (2008). Physical Activity and Environmental Influences during Secondary School Physical Education. Journal of Teaching in Physical Education, 28, 21-37.

Constantinides, P. (2011). Perceptions of Elementary Obese Students about Their Experiences in Physical Education: An Intervention Study. In A. MacPhail, \& M. O’Sullivan (Eds.), Proceedings of AIESEP International Conference, Limerick, 22-25 June 2011, 197-213. http://aiesep.org/wp-content/uploads/2014/11/Limerick-2011-Proceedings.pdf

Cothran, D. (2010). Students' Curricular Values and Experiences. In M. O’Sullivan, \& A. MacPhail (Eds.), Young People's Voices in Physical Education and Youth Sport (pp. 49-62). London: Routledge.

Dodds, P. (1985). Are Hunters of the Function Curriculum Seeking Quarks or Snarks? Journal of Teaching in Physical Education, 4, 91-99.

Fairclough, S. J. (2002). Girls' Physical Activity during High School Physical Education: Influences of Body Composition and Cardiorespiratory Fitness. Journal of Teaching in Physical Education, 22, 382-395.

Fairclough, S., \& Stratton, G. (2005a). Physical Activity Levels in Middle and High School Physical Education: A Review. Pediatric Exercise Science, 17, 217-236.

Fairclough, S., \& Stratton, G. (2005b). Physical Education Makes You Fit and Healthy. Physical Education's Contribution to Young People's Physical Activity Levels. Health Education Research, 20, 14-23. http://dx.doi.org/10.1093/her/cyg101

Fairclough, S., \& Stratton, G. (2005c). Improving Health-Enhancing Physical Activity in Girls' Physical Education. Health Education Research, 20, 448-457. http://dx.doi.org/10.1093/her/cyg137

Fairclough, S., \& Stratton, G. (2006). A Review of Physical Activity Levels during Elementary School Physical Education. Journal of Teaching in Physical Education, 25, 239-257.

Fisette, J. L. (2013). “Are You Listening?” Adolescent Girls Voice How They Negotiate Self-Identified Barriers to Their Success and Survival in Physical Education. Physical Education \& Sport Pedagogy, 18, 184-203. http://dx.doi.org/10.1080/17408989.2011.649724

Gao, Z., Hannon, J., \& Carson, R. (2009). Middle School Students' Heart Rates during Different Curricular Activities in Physical Education. ICHPER-SD Journal of Research, 4, 16-19.

Gehris, J., Myers, E., \& Whitaker, R. (2012). Physical Activity Levels during Adventure-Physical Education Lessons. European Physical Education Review, 18, 245-257. http://dx.doi.org/10.1177/1356336X12440365

Griffin, P. S. (1984). Girls' Participation Patterns in a Middle School Team Sports Unit. Journal of Teaching in Physical Education, 4, 30-38.

Griffin, P. S. (1985). Boys' Participation Styles in a Middle School Physical Education Team Sports Unit. Journal of Teaching in Physical Education, 4, 100-110.

Guba, E. G., \& Lincoln, Y. S. (1989). Fourth Generation Evaluation. Newbury Park, CA: Sage.

Gutierrez, D., \& García-López, L. M. (2012). Gender Differences in Game Behaviour in Invasion Games. Physical Education and Sport Pedagogy, 17, 289-301. http://dx.doi.org/10.1080/17408989.2012.690379

Hannon, J. C., \& Ratliffe, T. (2005). Physical Activity Levels in Coeducational and Single-Gender High School Physical Education Setting. Journal of Teaching in Physical Education, 24, 149-164.

Hodges Kulinna, P., Martin, L., Lai, Q., Kliber, A., \& Reed, B. (2003). Student Physical Activity Patterns: Grade, Gender Activity Influences. Journal of Teaching in Physical Education, 22, 298-310.

How, Y. M., Whipp, P., Dimmock, J., \& Jackson, B. (2013). The Effects of Choice on Autonomous Motivation, Perceived Autonomy Support, and Physical Activity Levels in High School Physical Education. Journal of Teaching in Physical Education, 32, 131-148. 
Jaakkola, T., Liukkonen, J., Laakso, T., \& Ommundsen, Y. (2008). The Relationship between Situational and Contextual Self-Determined Motivation and Physical Activity Intensity as Measured by Heart Rates during Ninth Grade Students' Physical Education Classes. European Physical Education Review, 14, 13-31. http://dx.doi.org/10.1177/1356336X07085707

Kalaja, S. (2012). Fundamental Movement Skills, Physical Activity, and Motivation toward Finnish School Physical Education: A Fundamental Movement Skills Intervention. Ph.D. Thesis, Jyväskylä: University of Jyväskylä. https://jyx.jyu.fi/dspace/bitstream/handle/123456789/38391/978-951-39-4817-7.pdf?sequence=1

Lauritsalo, K., Sääkslahti, A., \& Rasku-Puttonen, H. (2012). Student's Voice Online: Experiences of PE in Finnish Schools. Advances in Physical Education, 2, 126-131. http://dx.doi.org/10.4236/ape.2012.23022

Laurson, K. R., Brown, D. D., Cullen, R. W., \& Dennis, K. K. (2008). Heart Rates of High School Physical Education Students during Team Sports, Individual Sports, and Fitness Activities. Research Quarterly for Exercise and Sport, 79, 85-91. http://dx.doi.org/10.1080/02701367.2008.10599463

Locke, L. F. (1987). The Future of Research on Pedagogy: Balancing on the Cutting Edge (Vol. 20, pp. 83-95). American Academy of Physical Education Papers, Champaign, IL: Human Kinetics.

Lyyra, M., Heikiaro-Johansson, P., Johansson, N., \& McEvoy, E. (2008, January). Physical Activity Levels during PE Lessons. Poster Presented at the International Conference of AIESEP, Sapporo, Japan.

Marmeleira, J., CarrasqueiraAldeias, N., \& dos Santos Medeira da Graça, P. (2012). Physical Activity Levels in Portuguese High School Physical Education. European Physical Education Review, 18, 191-204.

http://dx.doi.org/10.1177/1356336X12440022

McKenzie, T. L. (1998). SOFIT: System for Observing Fitness Instruction Time. Overview and Training Manual. San Diego, CA: San Diego State University.

McKenzie, T. L., Marshall, S. J., Sallis, J. F., \& Conway, T. L. (2000). Student Activity Levels, Lesson Context, and Teacher Behavior during Middle School Physical Education. Research Quarterly for Exercise and Sport, 71, 249-259. http://dx.doi.org/10.1080/02701367.2000.10608905

McKenzie, T. L., Prochaska, J. J., Sallis, J. F., \& LaMaster, K. J. (2004). Coeducational and Single-Sex Physical Education in Middle Schools: Impact on Physical Activity. Research Quarterly for Exercise and Sport, 75, 446-449. http://dx.doi.org/10.1080/02701367.2004.10609179

Palomäki, S., \& Heikinaro-Johansson, P. (2011). Liikunnan oppimistulosten seuranta-arviointi perusopetuksessa 2010 [The Follow-Up Evaluation of Learning Outcomes in Physical Education in Basic Education 2010]. Koulutuk senrantaraportit, 4, Tampere: Tampereen Yliopistopaino.

http://www.oph.fi/download/131648_Liikunnan_seuranta-arviointi_perusopetuksessa_2010.pdf

Perlman, D. (2012). The Influence of the Sport Education Model on Amotivated Students' In-Class Physical Activity. European Physical Education Review, 18, 335-345. http://dx.doi.org/10.1177/1356336X12450795

Perlman, D. J. (2013). The Influence of the Social Context on Students In-Class Physical Activity. Journal of Teaching in Physical Education, 32, 46-60.

Pfeiffer, K. A., Pivarnik, J. M., Womack, C. J., Reeves, M. J., \& Malina, R. M. (2002). Reliability and Validity of the Borg and OMNI Rating of Perceived Exertion Scales in Adolescent Girls. Medicine \& Science in Sports \& Exercise, 34, $2057-$ 2061. http://dx.doi.org/10.1097/00005768-200212000-00029

Rowe, P. J., Schuldheisz, J. M., \& van der Mars, H. (1997). Measuring Physical Activity in Physical Education: Validation of the SOFIT Direct Observation Instrument for Use with First to Eighth Grade Students. Pediatric Exercise Science, 9 , 136-149.

Sarradel, J., Generelo, E., Zaragoza, J., Clemente, J. A., Abarca-Sos, A., Murillo, B., \& Aibar, A. (2011). Gender Differences in Heart Rate Responses to Different Types of Physical Activity in Physical Education Classes. Motricidad. European Journal of Human Movement, 26, 65-76.

Siedentop, D., Hastie, P., \& van der Mars, H. (2011). Complete Guide to Sport Education (2nd ed.). Champaign, IL: Human Kinetics.

Singerland, M., Oomen, J., \& Borghouts, L. (2011). Physical Activity Levels during Dutch Primary and Secondary School Physical Education. European Journal of Sport Science, 11, 249-257. http://dx.doi.org/10.1080/17461391.2010.506661

Slingerland, M. (2014). Physical Education's Contribution to Levels of Physical Activity in Children and Adolescents. Ph.D. Thesis, Maastricht: Maastricht University.

http://digitalarchive.maastrichtuniversity.nl/fedora/get/guid:c2c84964-7241-4883-909e-aec0ea4eab7e/ASSET1

Slingerland, M., Haerens, L., Cardon, G., \& Borghouts, L. (2014). Differences in Perceived Competence and Physical Activity Levels during Single-Gender Modified Basketball Game Play in Middle School Physical Education. European Physical Education Review, 20, 20-35. http://dx.doi.org/10.1177/1356336X13496000

Smith, B. T., \& Goc Karp, G. (1996). Adapting to Marginalization in a Middle School Physical Education Class. Journal of 
Teaching in Physical Education, 16, 30-47.

Spessato, B. C., Gabbard, C., \& Valentini, N. C. (2013). The Role of Motor Competence and Body Mass Index in Children's Activity Levels in Physical Education Classes. Journal of Teaching in Physical Education, 32, 118-130.

Stratton, G. (1996). Children's Heart Rates during Physical Education Lessons: A Review. Pediatric Exercise Science, 8, 215-233.

Subramaniam, P. R., \& Silverman, S. (2007). Middle School Students' Attitudes towards Physical Education. Teaching and Teacher Education, 23, 602-611. http://dx.doi.org/10.1016/j.tate.2007.02.003

Surapibooncha, K., Furney, S., Reardon, J., \& Murray, T. (2012). SAM: A Tool for Measurement of Moderate to Vigorous Physical Activity (MVPA) in School Physical Education. International Journal of Exercise Science, 5, 127-135.

Tischler, A., \& McCaughtry, N. (2014). Shifting and Narrowing Masculinity Hierarchies in Physical Education: Status Matters. Journal of Teaching in Physical Education, 33, 342-362. http://dx.doi.org/10.1123/jtpe.2012-0115

Tousignant, M., \& Siedentop, T. (1983). A Qualitative Analysis of Task Structures in Required Secondary Physical Education Classes. Journal of Teaching in Physical Education, 3, 47-57.

Treiber, F. A., Musante, L., Hartdagan, S., Davis, H., Levy, M., \& Strong, W. B. (1989). Validation of a Heart Rate Monitor with Children in Laboratory and Field Settings. Medicine and Science in Sports and Exercise, 21, 338-342. http://dx.doi.org/10.1249/00005768-198906000-00019

Van Acker, R., Carreiro Da Costa, F., De Bourdeaudhuij, I., Cardon, G., \& Haerens, L. (2010). Sex Equity and Physical Activity Levels in Coeducational Physical Education: Exploring the Potential of Modified Game Forms. Physical Education and Sport Pedagogy, 15, 159-173. http://dx.doi.org/10.1080/17408980902877609

Wallhead, T., Garn, A. C., Vidoni, C., \& Youngberg, C. (2013). Game Play Participation of Amotivated Students during Sport Education. Journal of Teaching in Physical Education, 32, 149-165.

Wydra, G. (2009). Belastungszeiten und Anstregungim Sportunterricht [Activity Time and Effort in Physical Education]. Sportunterricht, 58, 129-136. 
Scientific Research Publishing (SCIRP) is one of the largest Open Access journal publishers. It is currently publishing more than 200 open access, online, peer-reviewed journals covering a wide range of academic disciplines. SCIRP serves the worldwide academic communities and contributes to the progress and application of science with its publication.

Other selected journals from SCIRP are listed as below. Submit your manuscript to us via either submit@scirp.org or Online Submission Portal.
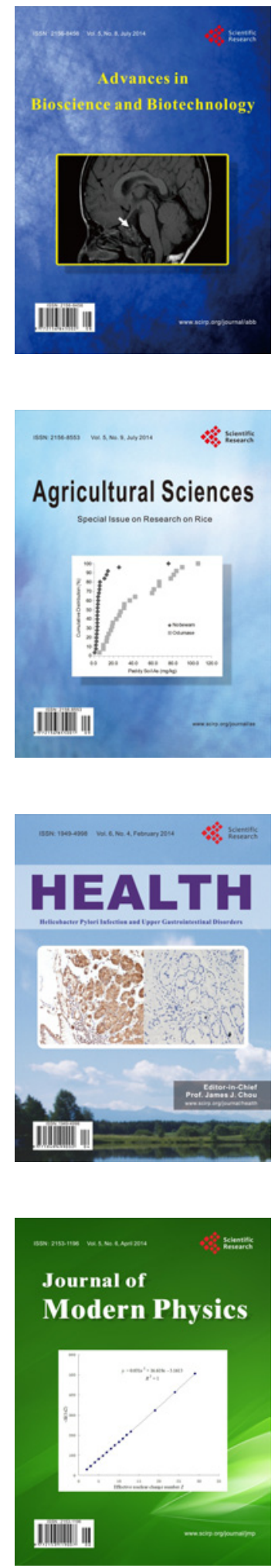
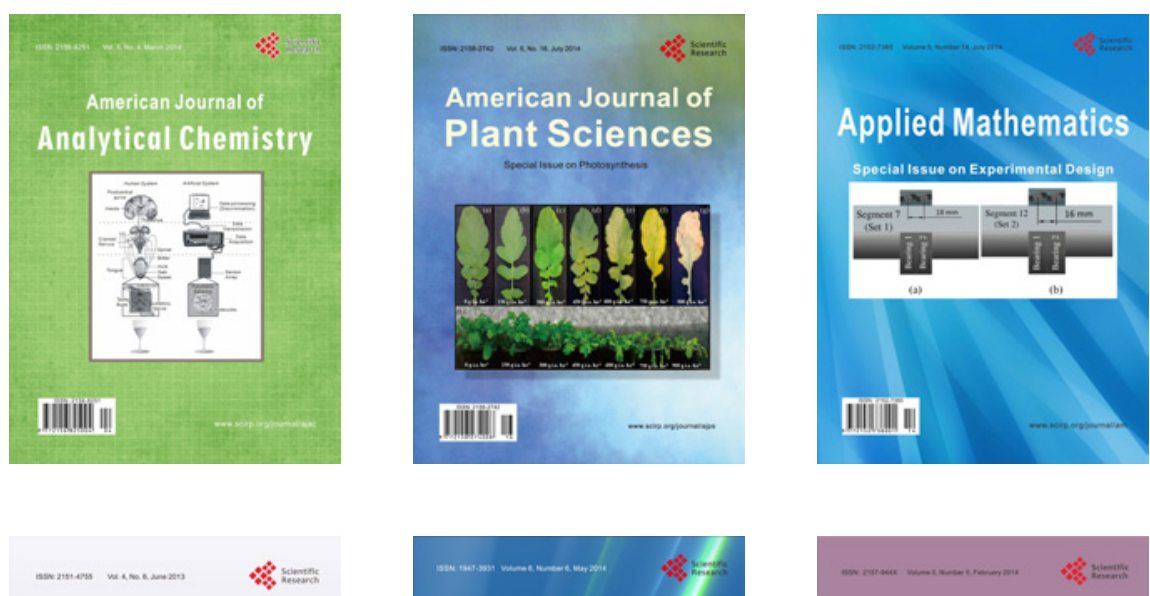

Creative Education
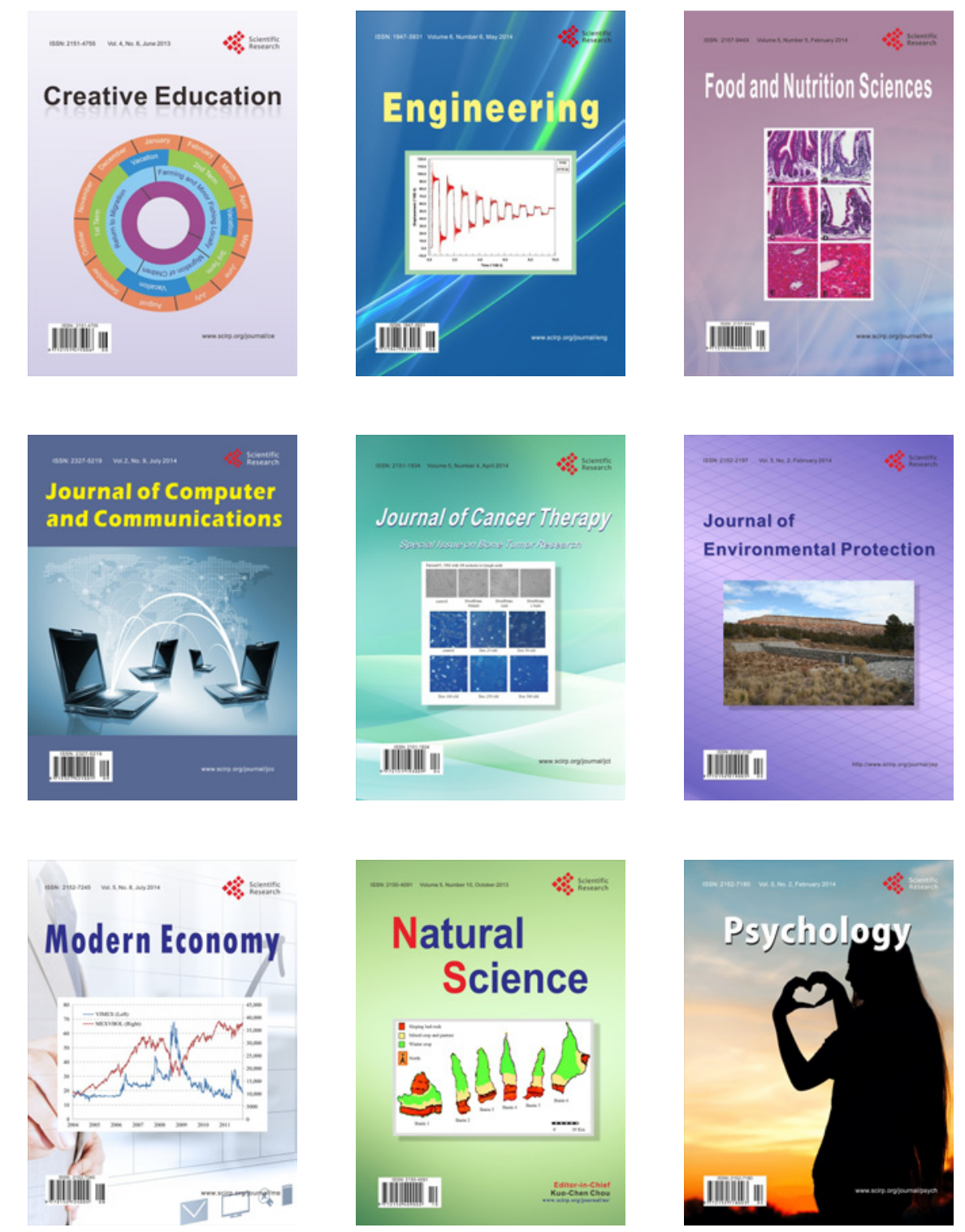